\title{
PENERAPAN METODE SIMPLE ADDITIVE WEIGHTING (SAW) DALAM MENENTUKAN KARAKTERISTIK LAHAN TERBAIK UNTUK TANAMAN UBI JALAR (Ipomoea batatas $L$.)
}

\author{
Muh. Fikruddin Buraerah Abd Hakim \\ e-mail: mfickru@gmail.com \\ Prodi Teknik Lingkungan, Universitas Bosowa \\ Jl. Urip Sumoharjo No.4, Sinrijala, Kec. Panakkukang, Kota Makassar, Sulawesi Selatan
}

\begin{abstract}
Abs trak
Keterbatasan pengetahuan dalam menentukan lokasi tanamubi jalar (Ipomoea batatas L.) yang banyak dilakukan oleh para petani masih belum sesuai dengan kaidah dasar karakteristik dan kesesuaian lahan yang sudah ditentukan berdasarkan beberapa penelitian terdahulu sehingga salah satu akibatnya adalah produktivitas yang tergolong rendah. Penelitian ini bertujuan untuk memberikan solusi kepada para petani dalam menetukan lokasi areal tanam ubi jalar dengan menerapkan metode alternatif pendukung keputusan. Metode penelitian yang digunakan adalah Simple Additive Weighting (SAW) dengan memberikan bobot preferensi pada kriteria pilihan, kemudian dari output metode tersebut menjelaskan rangking nilai tertinggi hingga terendah yang dapat dijadikan rekomendasi dalam menentukan lokasi tanam. Hasil penelitian yang telah dicapai menggunakan metode SAW memberikan informasi bahwa kriteria lahan terbaik dalam penanaman ubi jalar tertinggi ditemukan di Kecamatan Camba dengan nilai sebesar 89,8 sedangkan terendah ditemukan di Kecamatan Mandai dengan nilai sebesar 30. Oleh sebab itu, keberhasilan produktivitas yang paling optimal dan sesuai dengan kesesuaian lahan, sangat dianjurkan untuk dikembangkan pada areal intensitas curah hujan yang tinggi yang ditemukan pada Kecamatan Camba, Kabupaten Maros.
\end{abstract}

Kata kunci : Simple Additive Weighting (SAW), Ubi Jalar, Kesesuaian Lahan, Tanaman Pangan.

\section{Pendahuluan}

Perkembangan sub sektor pertanian tanaman pangan di Kabupaten Maros selama tahun 2008 mengalami kenaikan. Berdasarkan data yang diperoleh komoditi yang dominan dikembangankan meliputi: ubi jalar menempati areal dengan jumlah produksi 86,00 ton. Sedangkan komoditi yang paling rendah produksinya adalah kacang kedelai dengan jumlah produksi sebesar 11,10 ton. Jumlah produksi pertanian tanaman pangan di Kabupaten Maros dapat dilihat pada tabel berikut. [1]. Layanan kemudahan akses informasi dan komunikasi menjadi salah satu syarat penting bagi pembangunan pertanian berkelanjutan. Teknologi informasi dan komunikasi saat ini, ketika diterapkan pada daerah pedesaan yang dapat diakses oleh jaringan informasi dapat membantu meningkatkan komunikasi dan partisipasi masyarakat, menyebarluaskan informasi serta membantu berbagi pengetahuan dan keterampilan bagi penggunanya Penggunaan teknologi informasi memiliki peranan penting dalam suatu sistem penyuluhan pertanian karena dapat memberikan layanan penyuluhan dari berbagai sektor pertanian dan memainkan peranan penting dalam pembangunan pedesaan. Teknologi informasi dapat memperbaiki aksesibilitas petani dengan cepat terhadap informasi pasar, input produksi, tren konsumen, yang secara positif berdampak pada kualitas dan kuantitas produksi. ${ }^{[2] .}$ Ubi jalar (Ipomoea batatas Lamb.) merupakan salah satu tanaman pangan yang dapat digunakan untuk diversifikasi menu guna mempertahankan swasembada beras. Tanaman ini merupakan sumber karbohidrat penting selain padi, jagung, sagu, dan umbiumbian lainnya. ${ }^{\text {[3]. }}$ Bahkan di daerah tertentu khususnya bagian timur Indonesia dijadikan sebagai makanan pokok masyarakat. Tanaman ini \pm pada abad ke 16 diduga berasal dari Benua Amerika dan menyebar ke seluruh dunia terutama Negara-negara beriklim tropis. Orang-orang Spanyol menebarkannya ke kawasan Asia terutama Filipina, Jepang dan Indonesia. Cina merupakan penghasil ubi jalar terbesar mencapai $\pm 85 \%$ dari yang dihasilkan dunia. ${ }^{[4] . ~ R e n d a h n y a ~ p r o d u k s i ~ u b i ~ j a l a r ~ d i ~}$ Sulawesi Selatan dapat disebabkan beberapa kendala, antara lain rendahnya kwalitas bibit, tingginya gangguan hama dan penyakit serta tindakan kultur teknis yang belum baik. Gangguan hama dapat menurunkan produksi yang sangat nyata terutama hama yang menyerang umbi, faktor-faktor yang mempengaruhi kehidupaan hama C.formicarius adalah suhu, kelembaban udara, cahaya, angin, dan faktor makanan. Penyebab 
rendahnya hasil ubi jalar di tingkat petani karena ketergantungan petani masih menggunakan varietas lokal dan belum menggunakan varietas unggul. Lahan yang subur merupakan unsur yang penting bagi terciptanya kualitas kelapa sawit yang baik ${ }^{[5]}$. Untuk kriteria lahan ialah data sempel lahan yang akan diambil seperti curah hujan, topografi, lereng, kedalaman air, dan tekstur [6]. Agar mempermudah dan memberikan solusi bagi pengguna lahan dalam membantu pemilihan lahan terbaik diperlukan sebuah sistem pemilihan secara otomatis ${ }^{[7]}$. Dan dalam menemukan hasil tersebut pembuat perlu menggunakan SPK (Sistem Pendukung Keputusan) dan menggunakan Metode SAW (Simple Additive Weighting). Metode Simple Additive Weighting (SAW) dikenal dengan istilah metode penjumlahan terbobot. Konsep dasar metode SAW adalah mencari penjumlahan terbobot dari rating kinerja pada setiap altematif pada semua atribut. Metode SAW membutuhkan proses normalisasi matriks keputusan $(\mathrm{X})$ ke suatu skala yang dapat diperbandingkan dengan semua rating alternatif yang ada. Metode SAW mengharuskan pembuat keputusan menentukan bobot bagi setiap atribut. Skor total untuk alternatif diperoleh dengan menjumlahkan seluruh hasil perkalian antara rating (yang dapat di bandingkan lintas atribut) dan bobot tiap atribut. Rating tiap atribut harus sudah melalui proses normalisasi matriks sebelumnya. ${ }^{[8] .}$ Berdasarkan uraian di yang telah dijelaskan diatas, maka dibutuhkan metode yang menjadi rekomendasi dan pendukung keputusan dalam menentukan kesesuaian lahan tanaman ubi jalar. Oleh sebab itu, dilakukan penelitian mengenai penerapan metode simple additive weighting dalam menentukan karakteristik lahan terbaik tanaman ubi jalar (Ipomoea batatas L.) di Kabupaten Maros.

\section{Metode Penelitian}

Penelitian ini adalah analisis kuantitatif dengan menggunakan metode simple additive weighting (SAW). Penelitian ini bertujuan untuk mempermudah dan memberikan solusi bagi pengguna lahan dalam membantu pemilihan lahan terbaik untuk tanaman ubi jalar dengan menggunakan SPK (Sistem Pendukung Keputusan) dan menggunakan Metode Simple Additive Weighting (SAW). Langkah dalam melakukan penelitian ini yaitu pertama dengan melakukan literature review terhadap penelitian sebelumnya, langkah kedua menentuan kriteria karakteristik dan kesesuaian lahan, kemudian langkah ketiga, mendefinisikan kriteria tersebut dengan nilai bobot, langkah ke-empat membuat matrik keputusan, langkah kelima membuat matrik ternormalisasi dari matrik keputusan yang kemudian dilakukan pembobotan, dan terakhir mendapatkan rangking dari proses yang dilakukan. Alur tersebut dijelaskan pada Gambar 1.

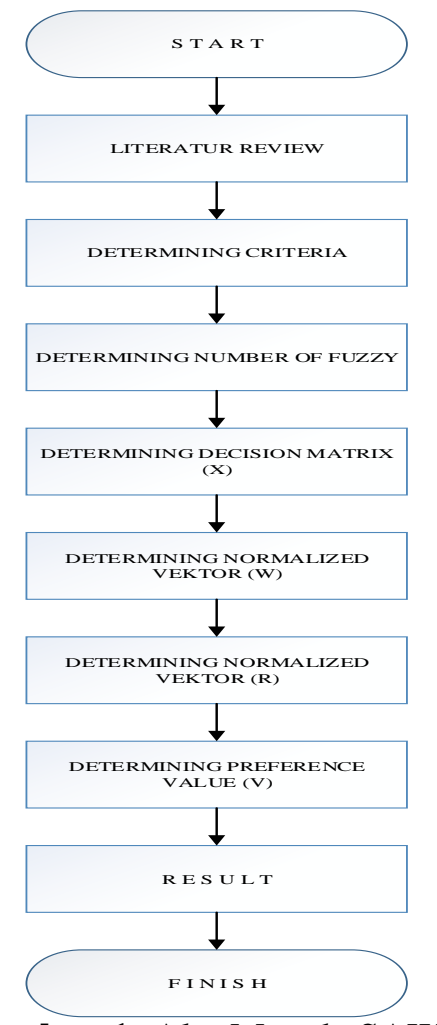

\section{Gambar 1. Alur Metode SAW}

Konsep dasar metode Simple Additive Weighting adalah mencari penjumlahan terbobot dari rating kinerja pada setiap alternatif pada semua atribut ${ }^{[9]}$. Metode ini membutuhkan proses normalisasi matriks keputusan (X) kedalam skala yang dapat diperbandingkan dengan semua rating alternatif yang ada. Skor total untuk alternatif diperoleh dengan menjumlahkan seluruh hasil perkalian antara rating dan bobot tiap atribut.

Dalam menentukan kriteria, hal yang akan dijadikan acuan dalam pengambilan keputusan, yaitu: 1. Menentukan rating kecocokan setiap alternatif pada setiap kriteria, 2. Membuat matriks keputusan berdasarkan kriteria, kemudian 3. Melakukan normalisasi matriks berdasarkan persamaan persamaan yang disesuaikan dengan jenis 
atribut (atribut keuntungan atau atribut biaya), 4. Membuat matriks normalisasi dan 5. Proses perankingan.

Formula yang digunakan

Formula untuk melakukan normalisasi

$$
r_{i j}=\left\{\begin{array}{c}
\frac{x_{i j}}{\operatorname{Max} x_{i j}} \text { Jika } j \text { adalah atribut benefit } \\
\frac{\operatorname{Min} x_{i j}}{x_{i j}}
\end{array}\right.
$$

dimana :

$=$ Rating kinerja ternormalisasi

$=$ Nilai maksimum dari setiap baris dan

$=$ kolom

$=$ Nilai minimum dari setiap baris dan

$=$ kolom

$=$ Baris dan kolom dari matriks

$=1,2,3, \ldots . . \mathrm{m}$

$=1,2,3, \ldots . . \mathrm{n}$

$V_{i}=\sum_{j=1}^{n} w_{j} r_{i j}$

dimana :

$=$ Nilai akhir dari alternatif

$=$ Bobot yang telah ditentukan

$=$ Normalisasi matriks

Data kriteria dan nilai bobot dapat dilihat pada Tabel 1, pengertian tiap criteria dapat dilihat sebagai berikut: 1 . Curah hujan adalah jumlah air yang jatuh pada periode tertentu, 2. Topografi adalah bentuk permukaan bumi dan karakteristik fisiknya 3 . Lereng adalah permukaan bumi yang membentuk sudut kemiringan tertentu dengan bidang horizontal, 4. Kedalaman air merupakan parameter yang penting dalam menentukan kondisi air tanah, 5. Keasaman tanah merupakan faktor penting yang mempengaruhi proses peyerapan unsur hara oleh akar tanaman.

Tabel 1. Tabel Kriteria

\begin{tabular}{cc}
\hline Kriteria & Keterangan \\
\hline $\mathrm{C} 1$ & Curah hujan \\
\hline $\mathrm{C} 2$ & Ketinggian \\
\hline $\mathrm{C} 3$ & Kedalaman Air \\
\hline $\mathrm{C} 4$ & Kemiringan lereng \\
\hline $\mathrm{C} 5$ & Keasaman tanah \\
\hline
\end{tabular}

Berdasarkan tabel kriteria yang terlampir, masing-masing bobot di klasifikasikan berdasarkan jenis nya, dalam menentukan bobot nilai dari masing-masing kriteria dapat diperoleh dengan membagi banyaknya jumlah bobot yang dimulai dari 0 dengan banyaknya jumlah nilai kriteria yang diberikan bobot dikurangi 1 .

\section{Hasil dan Pembahas an}

Berdasarkan analisis yang telah dilakukan, maka ditentukan pemilihan lahan terbaik untuk tanaman ubi jalar di Kabupaten Maros berdasarkan rumusan metode SAW yang telah dilakukan. Adapun kriteria-kriteria yang didapatkan dari data BPS Kabupaten Maros dan hasil penelitian terdahulu dituangkan pada tabel dibawah.

Kriteria pertama adalah curah hujan sebagai faktor penting untuk kesesauain lahan dilihat pada tabel 2 .

Tabel 2. Curah Hujan

\begin{tabular}{cc}
\hline Bobot & C1 \\
\hline Ringan & $<1250$ \\
\hline Sedang & $1251-1500$ \\
\hline Tinggi & $1501-1750$ \\
\hline Berat & $1751-3000$ \\
\hline
\end{tabular}

Kriteria kedua adalah ketinggian sesuai klasifikasi tinggi hingga rendahnya dilihat pada tabel 3 .

Tabel 3. Ketinggian

\begin{tabular}{cc}
\hline Bobot & C2 $(\mathbf{m})$ \\
\hline Rendah & $0-200$ \\
\hline Cukup & $200-300$ \\
\hline Menengah & $300-400$ \\
\hline Tinggi & $>400$ \\
\hline
\end{tabular}

Kriteria ketiga adalah kedalaman air sesuai klasifikasi berkisar antara kurang dari 50 meter hingga lebih dari 100 meter dilihat pada tabel 4.

Tabel 4. Kedalaman Air

\begin{tabular}{cc}
\hline Bobot & $\mathbf{C 3}(\mathbf{m})$ \\
\hline Kurang & $<50$ \\
\hline Sedang & $50-75$ \\
\hline Dalam & $76-100$ \\
\hline Sangat Dalam & $>101$ \\
\hline
\end{tabular}

Kriteria ke-empat adalah kemiringan lereng sesuai klasifikasi diukur dari datar, berombak, bergelombang berbukit hingga bergunung, dilihat pada tabel 5 .

Tabel 5. Kemiringan Lereng

\begin{tabular}{cc}
\hline Bobot & C4 (m) \\
\hline Rendah & Datar \\
\hline
\end{tabular}




\begin{tabular}{cc}
\hline Sedang & Bergelombang \\
\hline Cukup & Berbukit \\
\hline Ekstrim & Bergunung \\
\hline
\end{tabular}

Kriteria kelima adalah keasaman tanah sesuai klasifikasi diukur dari kurang dari 3,5 dan tertinggi 6,0 dilihat pada tabel 6 .

Tabel 6. Keasaman Tanah

\begin{tabular}{cc}
\hline Bobot & C5 $(\mathbf{m})$ \\
\hline Rendah & $<3,5$ \\
\hline Sedang & $3,6-4,0$ \\
\hline Cukup & $4,1-5,0$ \\
\hline Tinggi & $5,1-6,0$ \\
\hline
\end{tabular}

Lokasi yang terpilih dalam melakukan kriteria penanaman ubi jalar berdasarkan dari data Dinas Tanaman Pangan Kabupaten Maros untuk pangan ubi jalar ditemukan pada lokasi-lokasi yang ada pada tabel 7 dibawah ini.

Tabel 7. Luas Panen Ubi Jalar

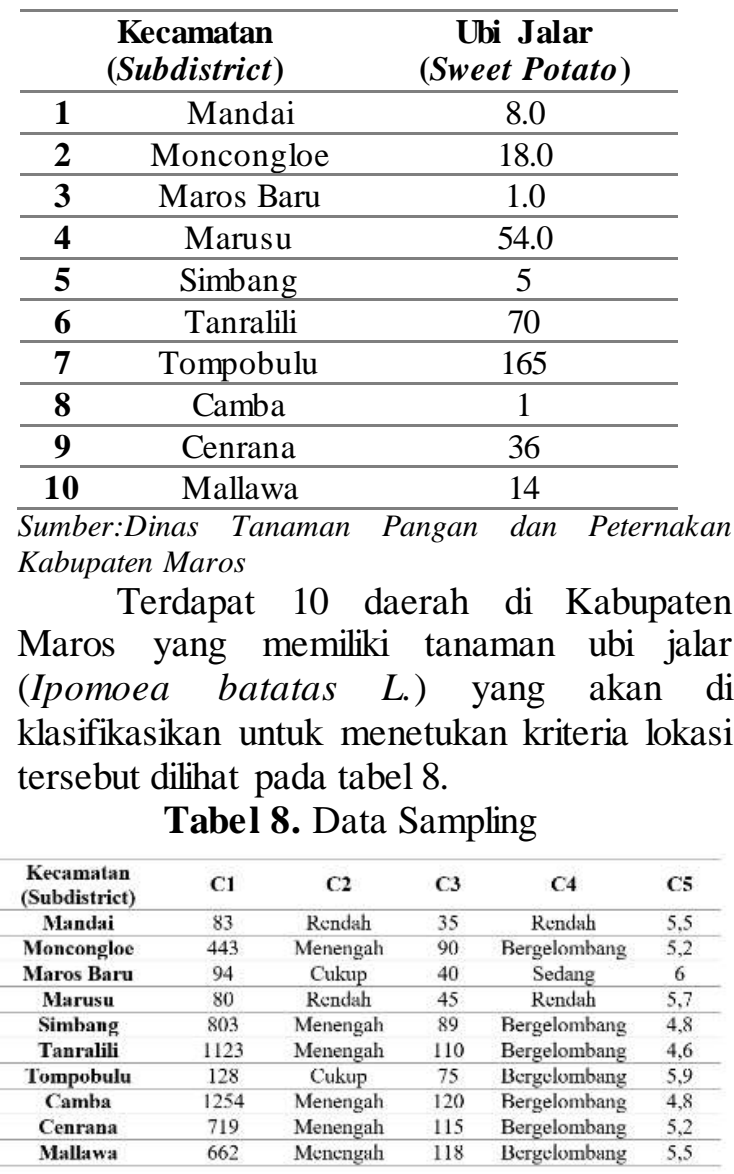

Kriteria pada tabel 9 di bawah ini menunjukkan hasil data sampling yang telah diberi rating kecocokan dari setiap alternatif yaitu dari kriteria $\mathrm{C} 1$ hingga $\mathrm{C}$.
Tabel 9. Penilaian Kriteria

\begin{tabular}{cccccc}
\hline $\begin{array}{l}\text { Kecamatan } \\
\text { (Subdistrict) }\end{array}$ & C1 & C2 & C3 & C4 & C5 \\
\hline Mandai & 0 & 0 & 0 & 0 & 1 \\
\hline Moncongloe & 0 & 0.66 & 0.66 & 0.66 & 1 \\
\hline Maros Baru & 0 & 0.33 & 0 & 0.33 & 1 \\
\hline Marusu & 0 & 0 & 0 & 0 & 1 \\
\hline Simbang & 0 & 0.66 & 0.66 & 0.66 & 0.66 \\
\hline Tanralili & 0 & 0.66 & 1 & 0.66 & 0.66 \\
\hline Tompobulu & 0 & 0.33 & 0.33 & 0.66 & 1 \\
\hline Camba & 0.33 & 0.66 & 1 & 0.66 & 0.66 \\
\hline Cenrana & 0 & 0.66 & 1 & 0.66 & 1 \\
\hline Mallawa & 0 & 0.66 & 1 & 0.66 & 1 \\
\hline
\end{tabular}

Setelah melakukan kriteria C1 hingga C5, langkah selanjutnya adalah membuat matriks keputusan yang dilihat pada tabel 10.

Tabel 10. Matriks $X$

\begin{tabular}{ccccc}
\hline $\mathbf{0}$ & $\mathbf{0}$ & $\mathbf{0}$ & $\mathbf{0}$ & $\mathbf{1}$ \\
\hline $\mathbf{0}$ & 0.66 & 0.66 & 0.66 & 1 \\
\hline $\mathbf{0}$ & 0.33 & 0 & 0.33 & 1 \\
\hline $\mathbf{0}$ & 0 & 0 & 0 & 1 \\
\hline $\mathbf{0}$ & 0.66 & 0.66 & 0.66 & 0.66 \\
\hline $\mathbf{0}$ & 0.66 & 1 & 0.66 & 0.66 \\
\hline $\mathbf{0}$ & 0.33 & 0.33 & 0.66 & 1 \\
\hline $\mathbf{0 . 3 3}$ & 0.66 & 1 & 0.66 & 0.66 \\
\hline $\mathbf{0}$ & 0.66 & 1 & 0.66 & 1 \\
\hline $\mathbf{0}$ & 0.66 & 1 & 0.66 & 1 \\
\hline
\end{tabular}

Kemudian melakukan normalisasi matriks yang merupakan perhitungan metode SAW dari hasil rating yang telah di range sehingga diperoleh matriks ternormalisasi $\mathrm{R}$ pada tabel 11.

Contoh proses normalisasi matriks $\mathrm{R}$

$$
r_{11} \frac{0}{\max (0,0,0,0,0,0,0,1,0,0)}=\frac{0}{1}=0
$$

Tabel 11. Matriks $\mathrm{R}$

\begin{tabular}{ccccc}
\hline $\mathbf{0}$ & $\mathbf{0}$ & $\mathbf{0}$ & $\mathbf{0}$ & $\mathbf{1}$ \\
\hline $\mathbf{0}$ & 1 & 0.66 & 1 & 1 \\
\hline $\mathbf{0}$ & 0.5 & 0 & 0.5 & 1 \\
\hline $\mathbf{0}$ & 0 & 0 & 0 & 1 \\
\hline $\mathbf{0}$ & 1 & 0.66 & 1 & 0.66 \\
\hline $\mathbf{0}$ & 1 & 1 & 1 & 0.66 \\
\hline $\mathbf{0}$ & 0.5 & 0.33 & 1 & 1 \\
\hline $\mathbf{1}$ & 1 & 1 & 1 & 0.66 \\
\hline $\mathbf{0}$ & 1 & 1 & 1 & 1 \\
\hline $\mathbf{0}$ & 1 & 1 & 1 & 1 \\
\hline
\end{tabular}

Kemudian langkah terakhir merupakan proses perangkingan nilai preferensi dari alternatif hasil matriks (R) dan bobot (W). Bobot yang telah ditentukan adalah $=20,20$, $10,20,30$.

$\mathrm{V} 1=(0)(20)+(0)(20)+(0)(10)+(0)(20)+(1)(30)=30$ $\mathrm{V} 2=(0)(20)+(1)(20)+(0,66)(10)+(1)(20)+(1)(30)=76,6$ $\mathrm{V} 3=(0)(20)+(0,5)(20)+(0)(10)+(0,5)(20)+(1)(30)=50$ $\mathrm{V} 4=(0)(20)+(0)(20)+(0)(10)+(0)(20)+(1)(30)=30$ 
$\mathrm{V} 5=(0)(20)+(1)(20)+(0,66)(10)+(1)(20)+(0,66)(30)=66,4$ $\mathrm{V} 6=(0)(20)+(1)(20)+(1)(10)+(1)(20)+(1)(0,66)=69,8$ $\mathrm{V} 7=(0)(20)+(0,5)(20)+(0,33)(10)+(1)(20)+(1)(30)=63,3$ $\mathrm{V} 8=(1)(20)+(1)(20)+(1)(10)+(1)(20)+(0,66)(30)=89,8$ $\mathrm{V} 9=(0)(20)+(1)(20)+(1)(10)+(1)(20)+(1)(30)=80$ $\mathrm{V} 10=(0)(20)+(1)(20)+(1)(10)+(1)(20)+(1)(30)=80$

Berdasarkan perangkingan/penentuan dari alternatif hasil matriks dan bobot, rangking tertinggi diperoleh di Kecamatan Camba dengan nilai 89,8 dan terendah Kecamatan Mandai dengan nilai 30. Dengan kata lain, berdasarkan kesesuaian lahan yang cocok ditanami ubi jalar berdasarkan urutan teratas hingga terbawah yang paling sesuai adalah Kec. Camba, Cenrana, Mallawa, Moncongloe, Tanralili, Simbang, Tompobulu, Maros Baru, Marusu dan Mandai, hasil tersebut dapat dilihat pada tabel 12 .

Tabel 12. Hasil Perangkingan

\begin{tabular}{ccc}
\hline $\begin{array}{c}\text { Kecamatan } \\
\text { (Subdistrict) }\end{array}$ & Nilai & Rangking \\
\hline Camba & 89.8 & 1 \\
\hline Cenrana & 80 & 2 \\
\hline Mallawa & 80 & 3 \\
\hline Moncongloe & 76.6 & 4 \\
\hline Tanralili & 69.8 & 5 \\
\hline Simbang & 66.4 & 6 \\
\hline Tompobulu & 63.3 & 7 \\
\hline Maros Baru & 50 & 8 \\
\hline Marusu & 30 & 9 \\
\hline Mandai & 30 & 10 \\
\hline
\end{tabular}

Hasil dari perangkingan ini menjelaskan bahwa terdapat perbedaan karakteristik lahan pada tiap kecamatan yang ada di daerah Kab. Maros, lahan yang paling sesuai dengan karakteristik dan kesesuaiannya di temukan pada Kec. Camba sehingga penanaman dan pengolahan ubi jalar pada lokasi tersebut sangat baik untuk dilakukan

\section{Kesimpulan}

Dari hasil penelitian penerapan metode Simple Additive Weighting (SAW) dalam menentukan karakteristik lahan terbaik untuk tanaman ubi jalar (Ipomoea batatas L.), dapat ditarik kesimpulan bahwa metode SAW dengan melakukan pembobotan sederhana pada kriteria curah hujan, ketinggian, kedalaman air, kemiringan lereng dan keasaman tanah dapat memberikan hasil akurasi yang tepat melalui proses perhitungan yang dilakukan. Nilai tertinggi yang diperoleh sebesar 89,8 pada Kecamatan Camba dan terendah sebesar 30 pada Kecamatan Mandai. Hal ini menunjukkan adanya potensi besar untuk ubi jalar tumbuh subur pada areal Kecamatan Camba berdasarkan beberapa penelitian pendukung yang mengatakan bahwa budidaya ubi jalar sangat cocok dilakukan di areal tropis yang lembab dan panas dengan intensitas curah hujan berkisar antara 750-1500 mm/tahun dengan suhu 21$27^{\circ} \mathrm{C}$. Pada penelitian selanjutnya dapat dimaksimalkan dengan penambahan kriteria yang lebih banyak lagi dari data yang beragam untuk mendapatkan hasil yang lebih maksimal dengan mempertimbangkan berbagai macam kondisi, serta mengkombinasikan dengan metode lain.

\section{Daftar Pustaka}

[1] Badan Pusat Statistik (BPS) Kabupaten Maros, 2015. Tanaman Pangan, https://maroskab.bps.go.id/subject/55/tan aman-pangan.html

[2] M. Dogan, T. Aktar, O. S. Toker, and N. B. Tatlisu, "Combination of the Simple Additive (SAW) Approach and Mixture Design to Determine Optimum Cocoa Combination of the Hot Chocolate Beverage," Int. J. Food Prop., vol. 18, no. 8, pp. 1677-1692, Aug. 2015.

[3] Sarwono, 2005.Ubi Jalar (Ipomea batatas poir). Jakarta.

[4] Rubatzky dan Mas Yamaguchi, 1998. Budidaya Ubi Jalar.Khodori.

[5] Khaswarina, S. 2001. Jurnal Natur Indonesia. Keragaman Bibit Kelapa Sawit Terhadap Pemberian Berbagai Kombinasi Pupuk di Pembibitan Utama. Fakultas Pertanian Universitas Sumatera Utara.

[6] Sabanise, Y. F., \& Rakhman, A. (2019). Sistem Pendukung Keputusan Penerimaan Beasiswa Dengan Menggunakan Metode Simple Additive Weighting (SAW) Studi Kasus Politeknik Harapan Bersama Tegal. Smart Comp: Jurnalnya Orang Pintar Komputer, 8(1), 48-53.

[7] Sholeh, R., Agus, F., Hatta, H. R., and Munawwarah, T., 2014, November. Analytical hierarchy process for land suitability analysis. In Information Technology, Computer and Electrical Engineering (ICITACEE), 2014 1st International Conference on (pp. 129132). IEEE. 